\title{
O Aval - Parte II
}

\section{SISTEMAS JURÍDICOS ESTRANGEIROS}

Newton de Lucca

Professor-Adjunto do Departamento de Direito Comercial

MARIO MATTEUCCI ${ }^{(4)}$ dividiu as legislações em três espécies:

"1a países que só admitem o aval no próprio título. Fora do título o aval seria apenas uma fiança extracambiária. Ex.: Alemanha, Áustria, Brasil, Itália e Suíça;

2: países que admitem o aval no próprio título ou em instrumento separado, ainda que, nesse último caso, nāo produza os mesmos efeitos da primeira hipótese. Ex.: França, Bélgica, Holanda, Espanha, Portugal, Argentina, Honduras, Guatemala, Costa Rica, México e Peru;

3- países que desconhecem o instituto do aval tal como se acha regulado no chamado direito continental. Ex.: Inglaterra e Estados Unidos.

Não parece de todo adequado que a distinção entre o sistema francês e o germânico seja feita a partir da possibilidade de ser o aval prestado em documento separado, como acontece no primeiro país.

A diferença existe, é verdade, sendo de todos conhecida a posição da delegação francesa na Convenção de Genebra, graças à qual foi editada a reserva do art. 13 do Anexo II, segundo a qual as Altas Partes Contratantes teriam a faculdade de admitir a possibilidade de ser dado um aval no seu território por ato separado em que se indique o lugar onde foi feito.

Mas a peculiaridade do sistema francês, a par da originalidade apontada no aspecto formal, é de natureza substancial e consiste em vislumbrar no instituto do aval uma espécie do gênero fiança, ainda que seja uma fiança "cambiária" ou uma fiança "sui generis".

(4) “Banca, Borsa i Titoli di Credito", parte prima, fasc. 3, págs. 142 a 154, 1934. 
A conseqüência de uma tal posição é que o aval passa a ter um caráter inteiramente acessório em relação à obrigação avalizada, não tendo a autonomia substancial consagrada nos sistemas alemão e italiano e adotada expressamente pela Lei Uniforme, conforme já tivemos a oportunidade de nos referir nas linhas introdutórias da presente exposição.

De resto, parece oportuna a classificação mencionada.

No que se refere ao direito anglo-americano, as garantias pessoais são admitidas, mas de maneira diversa da que costumamos conceber.

Tanto a suretyship quanto a guaranty podem ser aplicadas às obrigaçōes cartulares, mas somente a primeira poderia, tal como acontece com o nosso aval, subsistir na hipótese de nulidade da obrigação objeto da garantia prestada. A guaranty ao revés, permitindo que possam ser opostas as exceções próprias do devedor principal, aproxima-se do esquema francês, retromencionado.

A análise de tais institutos do direito anglo-americano revelará, contudo, numerosas nuances que, numa aproximação com o chamado direito continental, nem sempre encontram correspondência imediata.

O conceito da "consideration", por exemplo, não é exatamente traduzível em termos continentais, como anotou oportunamente ASCARELLI ${ }^{(1)}$, tendo havido nítida tendência de assimilá-lo ao conceito de "causa" o que levou juristas anglo-saxões a acusarem de "simplificação dogmática" tal tentativa ${ }^{(2)}$.

A Suretyship é definida pelo "Restatement of the law of security" como a relação existente quando alguém assume a obrigação de um terceiro que continua responsável perante o credor, devendo o pagamento ser feito de preferência por um dos obrigados, podendo o credor cobrar-se apenas uma vez.

SILVA PINTO, em precioso estudo ${ }^{(3)}$, mostra que

"há dois sentidos, um amplo e um restrito, para a Suretyship. Em sentido amplo, a Suretyship seria um contrato do qual uma pessoa (surety) assume a obrigação de uma cutra pessoa (principal), em atençāo a esta. Sob tal prisma, envolvendo várias formas

(1) "Teoria Geral dos Títulos de Crédito", Saraiva, 1943, ob. cit., pág. 103, nota de rodapé n" 5 da página anterior.

(2) Cir. MARIO ALBERTO BONFANTI e JOSÉ ALBERTO GARRONE, o. cit., pág. 140 e nosso ligeiro estudo "Aspectos da Teoria Geral dos Títulos de Crédito", Pioneira, 1979, págs. 41 e seguintes.

(3) "Direito Cambiário", Edição Revista Forense, Rio de Janeiro, 1948, capítulo V, págs. 149 e seguintes. 
de garantia, a Suretyship abrange näo apenas as garantias pessoais como também as reais.

Sctrito sensu - segundo o mencionado autor - suretyship é o contrato pelo qual um terceiro (surety) assume responsabilidade pelo débito, culpa ou delito de outra pessoa, obrigando-se por eles como o próprio obrigado principal".

O Dicionário da Barsa ${ }^{(4)}$ traduz Suretyship por "fiança", "garantia". Mas não deveremos tomar a palavra fiança no sentido técnico jurídico de nosso direito continental, embora sejam notorias as semelhanças entre os dois institutos.

Uma diferença está em que o surety, perante o credor da obrigação, é um devedor primário tal qual o devedor principal. Não lhe assiste o benefício de ordem existente na fiança, embora existam certas modalidades em que o surety somente poderá ser acionado se ocorrer o inadimplemento do devedor principal.

Outra diferença estaria no caráter não acessório da Suretyship.

No caso da nossa fiança, como é sabido, a nulidade da obrigação afiançada afeta visceralmente a própria garantia, nos termos da lei civil.

$\mathrm{Na}$ Suretyship, no entanto, pelo menos em certos casos a obrigação do surety subsistiria mesmo que inexistente a obrigação principal.

A Guaranty, por seu turno, consistiria fundamentalmente numa promessa de pagar, caso o obrigado principal esteja impossibilitado de fazê-lo.

Segundo o ensinamento de SILVA PINTO ${ }^{(1)}$ e numa tentativa de aproximação com o direito continental, poder-se-ia dizer que
"a guaranty teria maior correspondência cơn a nossa fiança civil, respeitado o benefício de ordem, enquanto que a Suretyship (sen- tido estrito) se aproximaria da fiança solidária, na qual o fiador abre mão dos benefícios e como é norma em direito comercial (2)"'.

No que toca ao direito alemão e italiano, já foi mostrada a principal diferença em relação ao sistema clássico francês.

(4) Verbete citado, pág. 539, volume I, "The New Barsa Dictionary of the English and Portuguese Languages".

(1) Ob. cit., pág. 154.

(2) Cfr. art. 258 do Código Comercial Brasileiro. 
De resto, toda a presente exposição estará a discorrer sobre o sistema ao qual se filia o nosso país.

\section{DISCIPLINA JURÍDICA}

Após a longa polêmica que se estabelecera em nosso país sobre a vigência das Leis Uniformes, o Supremo Tribunal Federal, primeiramente pelo R. E. no 70.356, do qual foi relator o Ministro BILAC PINTO, e posteriormente pelo R. E. $n^{\circ}$ 71.154, relatado pelo Ministro OSVALDO TRIGUEIRO, tornou pacífica, pelo menos sob o ponto de vista prático, a real integração, em nosso direito interno, daqueles diplomas legislativos.

Referidas Leis Uniformes foram introduzidas em nosso meio mediante a promulgação dos Decretos nos 56.663 e 57.595 , de 24 e 7 de janeiro de 1966 , respectivamente, o primeiro sobre letras de câmbio e notas promissórias e o segundo relativo aos cheques.

Pelo Decreto $\mathrm{n}^{\circ}$ 57.663, o nosso governo promulgou a Convenção para adoção de uma lei uniforme em matéria de letras de câmbio e notas promissórias, com as reservas previstas nos artigos $2^{\circ}, 3^{\circ}, 5^{\circ}, 6^{\circ}, 7^{\circ}, 9^{\circ}, 10^{\circ}, 13^{\circ}, 15^{\circ}$, $16^{\circ}, 17^{\circ}, 19^{\circ}$ e $20^{\circ}$ do Anexo II.

Como esclareceu, com propriedade, MERCADO JR ${ }^{(1)}$,

“a matéria objeto dessas reservas, ou já está regulada em nossas leis, ou nāo o está. No primeiro caso, as normas vigentes subsistirāo, como disposiçōes extravagantes, näo derrogadas pela Lei Uniforme, em virtude mesmo das reservas. No segundo caso, a eventual lacuna de nosso direito subsistirá enquanto não editadas normas que a supram".

Nenhuma das reservas subscritas pelo Brasil diz respeito à matéria de aval. Em conseqüência, a disciplina do aval estabelecida pela nossa legislação anterior (Decreto no 2.044, de 31 de dezembro de 1908) ficou toda derrogada pelo advento da Lei Uniforme, exceção feita, apenas, à possibilidade de

(1) "Nova Lei Cambial e Nova Lei do Cheque", edição Saraiva, 2ª edição, São Paulo, 1968. pág. 133. 
assinatura de mandatário especial, disposição que parece subsistir em razão da reserva do art. 20 do Anexo II, adotada pelo Brasil ${ }^{(1)}$.

Diante do exposto, não há dúvida de que o direito vigente em nosso país, em matéria de aval, é o que está disciplinado pelos arts. 30 e 32 da Lei Uniforme.

Já tivemos a ocasião de estudar, em linhas anteriores, o significado dos arts. 31 e 32, com suas importantes conseqüências.

Assim, sobra-nos nesse momento apenas o art. 30, assim redigido:

“O pagamento de uma letra pode ser no todo ou em parte garantido por aval.

Esta garantia é dada por um terceiro ou mesmo por um signatário da letra".

A primeira parte do artigo, como se vê, estabelece a possibilidade de ser o aval prestado parcialmente.

Nosso Decreto no 2.044 era omisso a respeito e, na doutrina, variavam as opiniões no tocante a tal possibilidade. Na prática, porém, não parece ter sido o aval parcial acolhido pela vida negocial. $\mathrm{O}$ instituto, com efeito, oferece algumas dificuldades no seu aspecto funcional.

O avalista que pagasse a soma parcial pela qual se obrigara teria a necessidade de obter de volta o título para agir regressivamente contra o devedor principal. Por outro lado, o portador do título, tendo interesse em receber o restante do valor do título, também teria necessidade de conservar o título em seu poder para fazer valer os seus direitos.

Como resolver-se o problema?

(1) O artigo 2 do Anexo II diz o seguinte.

"qualquer das Altas Partes Contratantes tem, pelo que respeita às obrigaçōes contraídas em matéria de letras no seu território, a faculdade de determinar de que maneira pode ser suprida a falta de assinatura, desde que por uma declaração autêntica escrita na letra se possa constatar a vontade daquele que deveria ter assinado".

Cumpre anotar, portanto, que o nosso Decreto n"2 2.044 , previa a assinatura do mandatário especial do sacador (art. 1", inciso V), do cndossador (art. 8", segunda alíncal), do aceitante (art. 11\% e, como frisamos no texto, do avalista (art. 14"). 
Parece que a única solução seria a de anotar-se no próprio título o pagamento parcial efetuado pelo avalista, extraindo-se as certidóes do mesmo por oficial público, nos termos do art. 365 do Código de Processo Civil Brasileiro. Trata-se, porém, de solução buscada fora do Direito Cambiário, sem base científica.

A segunda parte do artigo estabeleceu a possibilidade de ser o aval prestado tanto por um terceiro como por um dos signatários do título.

Cumpre anotar-se que, em nosso direito anterior, não havia disposição expressa no Decreto no 2.044. Alguns autores entenderam não ser possível o aval por quem já se obrigara no título.

SARAIVA ${ }^{(1)}$ por exemplo, argumentava que

“o coobrigado nāo pode intervir como avalista por lhe nāo ser facultado agravar sua responsabilidade além dos limites fixados por lei".

CARVALHO DE MENDONÇA ${ }^{(2)}$ também doutrinava que

“o avalista não deveria ser um dos coobrigados do título, uma vez que a sua responsabilidade em nada mudaria com o fato de prestar o aval".

A opinião desses dois grande autores não logrou prevalecer na doutrina. argumenta:

EUNÁPIO BORGES ${ }^{(3)}$, em relação à afirmação de SARAIVA, contra-

"É verdade que nenhum obrigado pode restringir ou agravar sua responsabilidade além dos limites fixados por lei (art. 44, 49), mas a autonomia e independência das obrigaçōes cambiais (pense-se na possibilidade de homonímia; o título nāo permite afirmar, logo, se se trata do mesmo obrigado ou de outro) autoriza qualquer coobrigado a assumir outra obrigaçāo, independente da primeira, cuja responsabilidade nem se restringe, nem se agrava".

(1) "A Cambial", \$9.

(2) "Tratado de Direito Comercial Brasileiro", no 753.

(3) Ob. cit., págs. 48 e 49. 
E contra o argumento de CARVALHO DE MENDONÇA sobre a inutilidade do aval prestado por quem já é obrigado no título, pondera o ilustre professor mineiro:

"O endossador que avaliza, equiparando-se ao aceitante, ao sacador, a um dos endossantes anteriores, exceçăo do que imediatamente o precede, robustece a garantia de pagamento com que contam todos os obrigados intermediários entre o endossadoravalista e aquele a que se equiparou".

A Lei Uniforme, conforme vimos, encerrou de vez a discussão, permitindo que o aval possa ser prestado tanto por um terceiro como por qualquer um dos signatários da letra.

Restaria mencionar, finalmente, a existência de um problema relativo ao aval não previsto em nenhum dos três artigos aqui examinados. Trata-se da questão, oportunamente lembrada por MERCADO JR ${ }^{(1)}$, do cancelamento do aval.

No regime do Decreto $n^{\circ} 2.044$ nenhuma dúvida existia. $O \S 1^{\circ}$ do art. 44 estabelecia que o endosso ou aval cancelado era considerado não escrito para os efeitos cambiais.

A Lei Uniforme previu, no art. 16, primeira alínea, o cancelamento do endosso. Previu, igualmente, no art. 29, o cancelamento do aceite, antes de restituída a letra pelo aceitante. Silenciou inteiramente, porém, quanto à possibilidade de cancelamento de aval.

Diante da omissão subsiste a dúvida: pode o aval ser cancelado?

\section{ELABORAÇĀO DOUTRINÁRIA DO AVAL}

O grande problema doutrinário do qual decorrem numerosas discussões é, sem dúvida, o relativo à autonomia da obrigação do aval e a sua exata posição em relação à cambial.

ROSSI (1) afirmou. com inteiro acerto, que

"a grande parte das questóes que surgem em matéria de aval é resolvida normalmente pela doutrina e pela jurisprudência com base

(1) Ob. cit., pág. 160.

(1) Ob. cit., pág. 23. 


\section{na atribuiçāo, freqüentemente apriorística, do caráter de autono- mia ou de acessoriedade que se reconhece na obrigação do ava- lista no confronto com a obrigaçāo do avalizado".}

É de notar-se, desde logo, que os conceitos de autonomia e de acessoriedade, além de não serem unívocos, se prestam a freqüentes divergências no que toca ao seu verdadeiro sentido e alcance, gerando opiniōes que, por estarem excessivamente presas à posição terminológica, acabam por determinar conseqüências jurídicas inaceitáveis.

Conexo com o retromencionado, embora dele diverso, poë-se o problema das relações entre o aval e a fidejussão.

Também aqui, como se verá, reconhecido o caráter de "acessoriedade" do aval à fidejussão, dilataram-se as discussões em torno da aplicação subsidiária das normas da segunda ao primeiro, partindo-se de um outro conceito unívoco que é o de "garantia" pessoal.

Sendo possíveis vários critérios no exame da elaboração doutrinária, nacional e alienígena, sobre a matéria do aval, parece interessante perquirir-se o pensamento da doutrina na medida em que se editavam, nos diferentes países, os grandes diplomas legislativos.

Desde logo, porém - e de forma declaradamente deliberada - deixaremos de lado a discussāo, de ranço totalmente acadêmico, relativa à natureza jurídica do aval (1), tão a gosto do enciclopedismo estéril, bizarro e alienante, viciado por um "essencialismo" cego, que julga tudo resolver em relação à pesquisa jurídica.

O que verdadeiramente importa, em matéria de aval, é determinar o exato conteúdo da obrigaçāo do avalista, daí extraindo-se todas as conseqüências importantes no que toca à subsistência dessa mesma obrigação em que pese a nulidade da obrigação do avalizado.

Importa, ainda, saber até que ponto essa subsistência vai gerar a inoponibilidade das exceçōes, por parte do avalista, porventura existentes em favor do avalizado.

(1) Cir., a propósito, a penetrante análise crítica feita por ALEGRIA (ob. cit., págs. 51 e seguintes) a propósito do conceito de "natureza jurídica", e particularmente no que se refere à natureza jurídica do aval. 
Importa, finalmente, saber se a obrigação do avalista é a mesma da do avalizado ou se é simplesmente da mesma natureza, sem ser exatamente a mesma obrigação. Mister esclarecer, enfim, o significado preciso da expressão legal "o dador do aval é responsável da mesma maneira que a pessoa por ele afiançada".

Ora, a "categorização" jurídica do aval, por si só, não responderá adequadamente a tais perguntas, sendo muito sábia a advertência de SILVA PINTO ${ }^{(2)}$ no sentido de que será sempre indispensável um exame da elaboração doutrinária do aval,

\footnotetext{
"sem que, no entanto, nos deixemos envolver pelo emaranhado sedutor das fórmulas vazias e das fúteis sutilezas que a dialética jurídica às vezes engendra, com esquecimento dos fatos e do verdadeiro objetivo da ciência do Direito".
}

Passemos ao exame das principais legislações e das interpretações doutrinárias a respeito.

O primeiro texto legislativo que disciplinou o instituto do aval foi a "Ordonnance du Commerce", de 1673.

Nada se disse, nesse texto, a respeito da acessoriedade do aval em relação à obrigação do avalizado. A doutrina francesa, porém, logo se pronunciou no sentido de que a natureza jurídica do aval era a de uma fidejussão, daí decorrendo, evidentemente, que a obrigação decorrente do aval somente seria válida na medida em que válida fosse a obrigação avalizada.

(2) “Ob. cit., pág. 196. O mesmo pensamento poderemos encontrar em EUNÁPIO BORGES (ob. cit., pág. 38):

"A discussāo puramente doutrinária em tomo de natureza jurídica do aval, sobretudo o problema de saber-se se essa garantia cambiária é ou não uma fiança, parecenos hoje desprovida de qualquer utilidade, não apresentando nenhum interesse prático. Sob esse ponto de vista, o que interessa 6 o estudo das disposiçōes positivas com que determinada legislação regula os efeitos que the atribui, a extensão da obrigaçāo que nele se contém, porque às indagaçōes exclusivamente teóricas e doutrinárias sobre o instituto assentaria a observaçáo de ARMINJON \& CARRY: 'Et l'on peut se demander si c'est la peine d'edifier des théories dont l'utilité pratique est douteuse, et qu'on me peut mantenir en Equilibre qu'en faisant appel aux règles particulières dont il s'agit justement de définir la nature' ". 
SAVARY ${ }^{(1)}$, provavelmente o mais destacado analista do mencionado diploma, considerou o aval como fiança, sendo a responsabilidade do avalista semelhante e solidária à do fiador.

Explica-nos SILVA PINTO ${ }^{(1)}$ que:

“tal solidariedade, expressa no art. 33 do título V da Ordonnance, já tinha sido reconhecida pela jurisprudência em Gênova e Paris. Mas, a doutrina e a jurisprudência até então dominantes - prossegue o citado autor - nāo permitiam a limitaçāo da garantia a uma determinada firma, ao contrário do que ficou depois estatuído no Code de Commerce".

Já na Wechselordnung alemã o aval não era especificamente disciplinado, limitando-se o art. 81 a fixar uma regra segundo a qual estaria obrigado cambialmente todo aquele que subscrever o saque, o aceite ou o endosso, embora apenas como garantia ${ }^{(2)}$.

A opinião prevalecente na doutrina parecia corresponder à posição que seria adotada pela Lei Uniforme de Genebra segundo a qual, como vimos, existe a autonomia substancial do aval e, ao mesmo tempo, acessoriedade formal.

Assim, era o aval considerado autônomo no sentido de que sua validade não seria afetada por eventuais vícios da obrigação garantida.

Mas, de outro lado, tal como logrou prevalecer até os dias atuais, existia uma dependência formal que se expressava, na época, ao que parece, na necessidade de aposição simultânea das firmas do avalista e do avalizado.

(1) "L'aval que l'on met sur les lettres et billets de change, et les autres sortes de billets concûs en la manière cidevant exprimée, n'est autre chose qu'une souscription que fait une personne qui s'obblige de payer, en cas que la lettre ne soit payée par celui sur qui elle est tirée, ou la somme portée par le billet, en cas que celui qui l'a fait ne l'acquitte aussi dans le temps échú: Ce mot d'A val signifie faire valoir la lettre ou le billet c'est-à-dire, les payer en cas qu'ils ne soient acquittés; c'est proprement une caution, car il n'est pas le principal preneur, n'y ayant que celui qui tire la lettre, ou qui fait le billet au profit d'une autre personne qui recoit les deniers; de sorte que ceux qui souscrivent ou donnent leur aval sur les lettres et billets, sont obligés avec les tireurs et raiscurs de billets", JACQUES SAVARY, 1 "Le Parfait Négociant", Genebra, 1752, 109.

(1) Ob. cit., pág. 192.

(2) Apud EUNÁPIO BORGES, ob. cit., pág. 21. 
De forma que, na doutrina alemã, nem vingou a tese que filiava o aval aos princípios da fiança ${ }^{(3)}$ nem tampouco a de que o mesmo era completamente autônomo, correspondendo a um novo saque, a um novo aceite ou a um novo endosso ${ }^{(4)}$.

É curioso observar o significado que tem, para a doutrina universal, o pensamento dos autores alemães. VIVANTE ${ }^{(5)}$ afirmava que a disciplina jurídica do aval era uma das mais controvertidas,

\title{
"seja porque nos falta o subsídio da legislaçāo e da doutrina ale- mã, onde é quase desconhecido esse instituto, seja porque ele tem dois aspectos jurídicos diversos, segundo consideremos o avalista perante o possuidor da cambial ou perante o avalizado..."
}

No direito italiano, inicialmente, propendia a doutrina francamente no sentido de considerar o aval como fiança comercial, considerando a obrigaçāo do avalista como dependente da obrigação do avalizado.

"Chi dice avallo, dice fideiussione", escrevia VIDARI (1), provavelmente influenciado pela doutrina francesa que, como vimos, vislumbrava no aval uma simples fiança.

Decisivamente contrário a tal concepção se postava BONELLI ${ }^{(2)}$ para quem

\begin{abstract}
“chiamar fidejussione una obbligazione che può nascere e persistere senza obbligazione principale è abusar delle parole: ciò che non è lecito al giurista, come a nessumo che voglia regionare scientificamente".
\end{abstract}

Tomando por base a 1 a alínea do art. 274 do Código Comercial de 1882, segundo a qual "o pagamento da cambial pode ser garantido por aval", entendia BONELLI que a obrigação do avalista seria inteiramente autônoma, per se stante como qualquer obrigação cambiária, pois o que se garante é o pagamento

(3) Cfr. WIELAND e MEYER, apud ROSSI, ob. cit., pág. 26.

(4) KUNTZE, BÖHLAU e BEYER, apud ROSSI, ob. cit., pág. 26.

(5) Ob. cit., pág. 318. Tal afirmação de VIVANTE foi vivamente contestada, entretanto, por ROSSI (Ob. cit., pág. 1, nota de rodapé n"- 1) que a considerou injustificada e mesmo ine

(1) "Lettera di cambio", Firenze, 1869, pág. 333.

(2) "Sulla Natura giuridica dell'avallo", Revista di Diritto Comerciale, vol. 9, 2" parte, págs. 116 e seguintes. 
da cambial e não o cumprimento da obrigação de determinado signatário do título ${ }^{(3)}$.

Finalmente, sustentou-se uma posição intermediária, segundo a qual o aval subsistiria como obrigação cambiária autônoma, independente da validade da obrigação garantida, mas subordinada à existência e validade desta última sob o ponto de vista formal, uma vez que, como asseverava VIVANTE ${ }^{(4)}$,

"non si capisce la garanzia di un'obbligazione che non esiste, perche non si garantisce il nulla".

Esclarece ROSSI ${ }^{(1)}$ que VIVANTE não teria tomado uma posição precisa sobre a natureza jurídica do aval.

É verdade que VIVANTE não se pronunciou especificamente sobre o problema da "natureza jurídica", mas parece segura a interpretação de seu pensamento no sentido da autonomia substancial e, ao mesmo tempo, da acessoriedade formal do aval, posição que corresponde, como vimos, à doutrina prevalecente na Alemanha e a que foi acolhida peio Direito Uniforme.

Relembre-se, em primeiro lugar, que VIVANTE criticara a qualificação de "garantia objetiva" feita por BOLAFFIO e adotada por autores como BONELLI e MESSINEO (2), apresentando razōes "decisivas" para condenar tal expressão.

Em segundo lugar, essa interpretaçāo parece defluir naturalmente do trecho retromencionado, que para maior alcance e clareza, passamos a reproduzir:

“L'avallante deve dichiarare per chi oresta l'avallo ed è libero nella scelta, purchè lo dia per un obbligato cambiario. Può darlo anche per una persona la cui forma non figura ancora sulla cambiale, e sarà un'obbligazione subordinata all'esistenza futura della firma principale (n.1111). Ma se la persona per cui à dato l'avallo non vi appone la firma, o ne l'appone con un segno di croce $o$ in una forma non amessa dal diritto cambiario, l'avallo deve ritenersi inefficace. Si obietterà che le obbligazioni cambiarie sono autonome. Certo lo sono quando esistono, ma se manca una condizione essenziale per la loro esistenza non è più il caso di autonomia,

(3) Apud SILVA PINTO(), ob. cir., pág. 201.

(4) Ob. cit., \$1225, pág. 321.

(1) Ob. cit., púg. 29, nota de rodapé n" 15.

(2) Conforme exposto anteriormente no item III. 
perchè ciò che non esiste non può essere autonomo o non autonomo. Anche la firma dell'accettante è autonoma, ma essa è inetta a produrre effeti cambiari se al titolo manca la firma principale del traente: cosi è dell'avallo se, quando si vorrebbe farlo valere, manca la firma principale dell'avallato, necessaria alla sua esistenza. Si obietterà che la legge dice valida l'obbligazione dell'avallante ancorchè non lo sia quella dell'avallato. Ma altro è invalido, altro è inesistente; si capisce la garanzia di un'obbligazione non valida, ad es., per visio di capacità, o di consenso, perchè l'obbligazione invalida esiste finchè non sia annullata, e quindi può essere garantita contro i suoi vizi; non si capisce la garanzia di un'obbligazione che non esiste, perchè non si garantisce il nulla".

Outro grande autor italiano cujo pensamento parece claro no mesmo sentido é NAVARRINI.

Para esse autor, o aval é

"uma garantia e, como tal, formalmente acessónio, requerendo a
existência de uma cambial válida e perfeita em sua aparência. O
aval seria uma forma e garantia que teria resultado de uma pro-
funda transformaçāo da fiança no que diz respeito à substância da
relaçāo. O avalista, ao firmar a cambial, assume uma obrigaçāo
autônoma e abstrata, atributos essenciais da obrigaçäo cambiária
que predominam em matéria de aval. A acessoriedade - atributo
fundamental da fiança - nāo existiria quanto à matéria, mas sub-
sistiria no tocante à validade formal da obrigaçāo do avaliza-
do"(1).

Passemos, finalmente, à doutrina nacional, a respeito da qual algo já foi dito no item III, retro.

Informa-nos SARAIVA ${ }^{(2)}$ que o nosso Código Comercial não disciplinou o aval, apenas fazendo referência ao "abono", no art. 380, que facultava ao portador, no caso de protesto pela faltâ de pagamento da letra de câmbio aceita, o exercício da ação contra os abonadores do aceitante. Pelo art. 422 do mesmo Código, era estabelecida a responsabilidade solidária dos abonadores.

(1) Apud SILVA PINTO, ob. cit., pág. 203.

(2) Ob. cit., \$91, págs. 269 e 270. 
Concluia o ilustre jurista pátrio que

"do sistema do nosso código, podemos com segurança inferir que o abono cambial era fiança solidánia, que inibia ao abonador executado prevalecer-se do benefício de oferecer à penhora os bens do abonado".

"Sem embargo, porém, da solidariedade - arremata o jurista - o abono cambial conservava a feiçāo de vínculo acessório, que, para a sua subsistência legal, reclamava a existência e a validade da obrigaçāo do abonado".

Tal como fora regulado, o "abono" se apresentava como fiança mercantil solidária, de natureza muito semelhante à do aval, tal como se delineara esse instituto na França, de quem o nosso país recebera influência até o advento do Decreto n².044, de 31 de dezembro de 1908.

Não havia, porém, uma conceituação pacífica em torno do "abono", sendo certo, por um lado, como assinalou CARVALHO DE MENDONÇA (1), que a jurisprudência, "apesar das obscuridades e contradiçōes nos seus julgados", o distinguia da fiança, enquanto outros julgados, de outro lado, empregaram a expressão aval como equivalente a abono ${ }^{(2)}$.

Aos 31 de dezembro de 1908, de "ascendência sabidamente germânica" no dizer de EUNÁPIO BORGES ${ }^{(3)}$, oriunda do projeto elaborado por SARAIVA, era editada uma nova lei cambial brasileira: o Decreto 2.044 que veio alterar profundamente o nosso sistema cambial.

Eram três os artigos do texto legal direta ou indiretamente relacionados com o aval: o art. 14, o art. 15 e o art. 43, a seguir transcritos.

“Art. 14 - O pagamento de uma letra de câmbio, independente do aceite e do endosso, pode ser garantido por aval. Para a validade do aval, é suficiente a assinatura do próprio punho do avalista ou do mandatário especial, no verso ou no anverso da letra". "Art. 15 - O avalista é equiparado àquele, cujo nome indicar, na falta de indicaçāo, àquele abaixo de cuja assinatura lançar a sua; fora desses casos, ao aceitante e, não estando aceita a letra, ao sacador".

(1) Ob. cit., pág. 348, continuação da nota de rodapé n² 1 iniciada na pág. 347.

(2) Ob. cit., pág. 222. Quanto à utilização da expressão "abonar" como sinônima de avalizar, cfr. com a áspera crítica de EUNÁPIO BORGES (ob. cit., págs. 39 e 40).

(3) Ob. cit.. pág. 40. 
"Art. 43 - As obrigaçōes cambiais sāo autômas e independentes umas das outras. $O$ signitário da declaraçāo cambial fica, por ela, vinculado e solidariamente responsável pelo aceite e pelo pagamento da letra, sem embargo da falsidade, da falsificaçāo ou da nulidade de qualquer outra assinatura".

Autor do projeto que culminou com o advento do Decreto 2.044, assim se expressou SARAIVA ${ }^{(1)}$ :

"A nossa legislaçäo é a que melhor disciplina o instituto do aval. Simples, harmônico e perfeito, é o sistema adotado.

A lei cambial brasileira desconhece obrigaçōes acessórias; cada uma delas é autônoma, $e$ independente das outras, para o efeito da garantia completa do direito creditório do portador.

O signitário do aval, cambialmente vinculado, fica solidariamente responsável pelo aceite e pelo pagamento do título, sem embargo da falsidade, ou da falsificaçāo, ou da nulidade de qualquer outra assinatura (art. 43).

Abstrata como é a obrigaçāo cambial, influência alguma pode exercitar a causa da intervençāo do avalista.

Ele fica vinculado pela declaraçāo unilateral da vontade expressa em título destinado à circulaçāo.

Para que a cambial circule com facilidade e segurança, o legislador brasileiro veda o exame da causa do vínculo e das relaçōes jurídicas preexistentes no saque, no endosso, no aceite, na intervençäo e no aval".

Vê-se, portanto, que o ilustre jurista tinha posiçāo bastante radical e diametralmente oposta ao conceito francês do aval-fiança.

Equivocou-se naturalmente JOĀO ARRUDA (1) ao interpretar a posição de SARAIVA no mesmo sentido da de VIDARI, segundo a qual seria o aval uma espécie do gênero fiança ${ }^{(2)}$.

Ora, como se não bastasse o trecho já transcrito, afirmava SARAIVA (3):

"Por haver subscrito o saque, o avalista fica vinculado com o sacador, e equiparado ao co-sacador.

(1) Ob. cit., § 96, págs. 283 e 284 .

(1) Decreto 2.044, I volume, Escolas Profissionais Salesianas, 19]4, São Paulo, pág. 65.

(2) Sobre o equívoco de ARRUDA, cfr. EUNÁPIO BORGES (ob. cil., pág. 41 ).

(3) Ob. cit., págs. 284 e 285. 
Por haver subscrito o endosso, o avalista fica vinculado como o endossador, e equiparado ao co-endossador.

Por haver subscrito o aceite, o avalista fica vinculado como o aceitante, e equiparado ao co-aceitante.

Por haver subscrito a intervençäo, o avalista fica vinculado como o interveniente, e equiparado ao co-interveniente reclamado ou voluntário (art. 1).

Por nāo haver declarado qual a firma honrada, pela presunçāo juris et de jure de haver querido honrar todas as firmas, 0 avalista fica vinculado como o aceitante, ou como o emitente, conforme a hipótese, e equiparado ao co-aceitante, ou ao co-sacador da letra de câmbio, ou ao co-emitente da nota promissória.

Estabelecidas estas normas, facílima será a solução dos casos ocorrentes; conforme a hipótese, para os efeitos cambiais, o avalista é o sacador da letra de câmbio, ou o emitente da nota promissória, ou o endossador, ou o aceitante ou o interveniente".

Essa posição de SARAIVA parece ter sido acompanhada pela maioria de nossos doutrinadores, pronunciando-se claramente no mesmo sentido, entre outros, CARVALHO DE MENDONÇA e EUNÁPIO BORGES.

Quanto ao primeiro, assim se expressou o grande jurista ${ }^{(4)}$ :

"Não obstante o seu escopo seja fortalecer o crédito de uma das firmas signatárias da letra de câmbio, é o aval, na sua essência, obrigaçäo cambial, e portanto:

a) obrigaçäo formal, decorrendo da simples assinatura do avalista, pouco importando a sua causa ou origem;

b) obrigaçāo autônoma e independente das outras, que figuram na letra, e como tal vincula solidariamente o avalista pelo pagamento da letra de câmbio e produz efeito sem embargo de falsidade, da falsificaçäo ou da nulidade da assinatura da pessoa avalizada; e finalmente;

c) obrigaçāo pessoal e direta do avalista para com o portador da letra. $O$ avalista, tomando-se codevedor, chama sobre si todos os direitos e obrigaçōes da firma que garante".

Em seguida conclui CARVALHO DE MENDONÇA:

"Para bem caracterizar a natureza do aval, a lei 2.044, de 1908, no art. 15, declarou que o avalista seria equiparado ao devedor,

(4) "Tratado de Direito Comercial Brasileiro", Vol. V, Parte II, Rio de Janeiro, 1922, § 748 , págs. 348 e 349. 
cujo nome indicasse, e, na falta de indicaçāo, aquele abaixo de cuja assinatura lançasse a sua, $\mathbf{e}$, fora desses casos, ao aceitante, e, nāo estando aceita a letra, ao sacador".

E remata:

"A lei quis, nestes termos, dizer que o avalista representa novo sacador, novo aceitante, novo endossador, conforme prestasse o aval a favor de algum desses obrigados na letra de câmbio".

EUNÁPIO BORGES ${ }^{(1)}$, na mesma linha de pensamento, afirmou categórico:

"De acordo, pois, com os termos claros de nossa Lei Cambial (arts. 14, 15 e 43), com os ensinamentos de SARAIVA, CARVALHO DE MENDONÇA E WHITAKER, conceituo o aval como garantia cambial típica, cuja finalidade exclusiva é garantir o pagamento da letra de câmbio ou da nota promissória, do mesmo modo que o garantiria o coobrigado cambial, ao qual se equipara, se perfeitamente válida fosse a obrigação deste, à qual a do avalista nāo se subordina por nenhum vínculo de acessoriedade, quer material, quer formal".

Não há dúvida de que a lição de SARAIVA, acompanhada pelos autores que acabamos de citar, representou contribuição doutrinária de relevo para retirar-se o instituto do aval dos acanhados limites que lhe traçou a concepção francesa, atrelando-o à fiança.

Por outro lado, como afirma com precisão SILVA PINTO ${ }^{(1)}$, essa teoria "está eivada de exagerado objetivismo", circunstância que levou SARAIVA "a negar a existência de qualquer coisa de comum entre aval e fiança, e a afirmar a absoluta autonomia fomal e substancial do aval em direito brasileiro".

Vimos, linhas atrás, a referência de EUNÁPIO BORGES ao Decreto 2.044, no que toca à "ascendência sabidamente germânica" desse último.

Sucede que, nesse particular, não parece de rigor científico se equiparar a posição do Decreto 2.044 à concepção germânica ${ }^{(2)}$, a menos que por esta última se tome a posição de KUNTZE, de BÖHLAU e de

(1) Ob. cit., pág. 44.

(1) Ob. cit., pág. 224.

(2) A afirmação do Prof. EUNÁPIO BORGES íob. cit., pág. 4()) ć feita exclusivamente a propósito do conceito de SARAIVA sobre o aval. 
BEYER, o que, como vimos anteriormente, corresponde a uma parte da doutrina alemã e não à doutrina que logrou prevalecer naquele país.

Aliás, o próprio Prof. EUNÁPIO BORGES, à pág. 28, é preciso na explicação da doutrina alemã:

"Para a doutrina alemã dominante, o aval é ato substancialmente autônomo e independente da obrigaçāo garantida, da qual é apenas formalmente dependente". (grifos nossos).

Tanto SARAIVA, quanto CARVALHO DE MENDONÇA e EUNÁPIO BORGES, na verdade, se afastam da doutrina alemã dominante, posto não reconhecerem a acessoriedade formal do aval.

SILVA PINTO ${ }^{(1)}$, de outro lado, afirmava não ver razões para não se adotar, em face da lei brasileira, a doutrina que pareceu acertada em face da Lei Uniforme, concluindo logo adiante:

"Afirmar a possibilidade de subsistência da obrigaçāo do avalista mesmo em caso de inexistência formal da obrigação avalizada parece-nos contrariar a natureza das coisas, pois importa em permitir que a garantia se efetive quando lhe falte, nāo o objeto, que é o pagamento da soma cambiária, mas o apoio material no título, o elo a que se prende a garantia e que lhe atribui, por equiparaça de posiçōes, limites precisos, estabelecendo os direitos e deveres do avalista".

A introdução da Lei Uniforme em nosso direito tornou inteiramente superada a presente discussão uma vez que, conforme foi visto já nas linhas introdutórias da presente exposição, os termos do artigo 32 são absolutamente decisivos quanto à autonomia substancial e quanto à acessoriedade formal do aval $^{(2)}$.

(I) Or. cit., pág. 226.

(2) O próprio EUNÁPIO BORGES (ob. cit., pág. 45) esclarece, com precisão, que a Lei Unilorme consagra posiçāo diferente da sua, calcada no Decreto 2.044:

"Isso-fique bem claro-em face da nossa lei no 2.044 .

Na Lei Uniforme nāo é assim, uma vez que seu art. 32, de modo expresso, consagrou, an lado da autonomia substancial do aval, sua acessoriedade formal em relaçāo à obrigaçāo avalizada". 
ASCARELLI, a nosso ver, expôs com propriedade o caráter de dependência existente no aval ${ }^{(3)}$ :

"A acessoriedade do aval revela-se na sua dependência da validade extrínseca da obrigaçāo do avalizado e no direito cambiário do avalista para com o avalizado, e para com aqueles que responderiam perante este; a sua autonomia revela-se na sua independência da validade intrínseca da obrigaçāo do avalizado (art. 37 da lei cambiária).

A funçāo de garantia dessas obrigaçōes nāo importa na subtração aos princípios das obrigaçōes cambiárias; elas também são assumidas em virtude de uma relaçāo fundamental, diferente nas várias hipóteses concretas; representam obrigaçōes autônomas, abstratas, constituídas objetivamente a favor do portador do título".

Cumpre registrar, por fim, que a consagração do princípio da autonomia substancial e da acessoriedade formal do aval pela Lei Uniforme, aliás correspondente à prevalecente posição da doutrina italiana e alemã sobre a matéria, não significa a solução de todos os problemas práticos.

A disciplina das exceçōes continua a oferecer percalços para a doutrina e para a jurisprudência, parecendo plenamente procedente aquela afirmação de ASCARELLI ${ }^{(1)}$ segundo a qual "talvez seja justamente o aval a obrigaçāo cuja natureza cambiária se evidenciou com maior dificuldade".

Passemos, agora, às linhas conclusivas de nossa tarefa, onde tentaremos, justamente, responder às indagaçōes levantadas ao longo do trabalho e que dizem respeito à autonomia substancial do aval, plenamente reconhecida no plano legislativo, doutrinário e jurisprudencial, conforme se verificou, sem que se estimasse, entretanto, a exata conseqüência da adoção desse princípio no tocante à completa desvinculação da obrigação do avalista em relação à obrigação do avalizado.

\section{CONCLUSÃO FINAL}

A natureza cambiária da obrigação do avalista - evidenciada com dificuldade na doutrina, como afirmou ASCARELLI - está a ensejar, ainda, certas incompreensões relativamente à extensão e ao alcance da autonomia substancial do aval.

(3) "Teoria Geral dos Títulos de Crédito", Saraiva, 1943, pág. 220, nota de rodapé n" I, 20 e 3 parágrafos.

(1) Ob. cit., pág. 127, nota de rodapé n" 1, último parágrafo. 
Se as conclusões a que chegamos nos capítulos anteriores nos autorizariam a afirmar que se achariam circunscritas a certos pontos determinados as controvérsias existentes, parecendo mesmo que os princípios da autonomia substancial e o da acessoriedade formal, acolhidos pela Lei Uniforme, não estariam a suscitar maiores perplexidades - tirante aquelas que a doutrina terá se esmerado em sublinhar e que, de forma sumária, relatamos ao longo do presente estudo - vez por outra desponta ainda, em nossa jurisprudência, indisfarçável hesitação quanto à aplicação daqueles princípios próprios do Dıreito Cambiário, quiçá pela dúvida que se coloca no espírito do julgador de que referida aplicação não corresponda à intuição que ele tem do que seja justo, na apreciação daquele caso concreto.

A autonomia substancial do aval, que tão importantes conseqüências acarreta, a ponto de fazer com que subsista a obrigação do avalista ainda que nula a obrigação do avalizado (a não ser que tal nulidade decorra de vício de forma), foi consagrada, evidentemente, tendo em vista a prevalência do interesse do credor de um título de crédito e, por via da conseqüência, a predominância do interesse geral da coletividade no sentido de que as riquezas pudessem circular com a maior facilidade possível.

Essa circulação da riqueza, que corresponde a uma exigência econômica dos tempos modernos, só pôde ser eficazmente atingida graças à "densa rede" dos títulos de crédito, ilustrada está em páginas decisivas pelo gênio exuberante de ASCARELLI.

Não será exagerado afirmar, por certo, que a função predominantemente circulatória dos títulos de crédito (que terá levado juristas como WINIZKY a preferir à expressão tradicional "títulos de crédito' a de "títulos circulatórios") serve, só por si, para explicar o papel que é desempenhado pelo aval nesse terreno, conforme a oportuna explicação de ALEGRIA.

Se é certo, assim, que o aval representa um reforço de garantia que, sob o ponto de vista da realidade econômica, colabora na função de circulação inerente aos títulos de crédito, não se poderá deixar em nível secundário a consideração de que, colocada no primeiro plano de prioridades essa mesma função, não deverá ela ser arredada, apenas, pela invocaçāo de um vago sentido de eqüidade ou pela mera intuiçāo de que o caso concreto deva merecer outra soluçāo.

A hesitaçāo que naturalmente envolve o julgador na aplicação de certos princípios cambiários, justificáveis e até desejáveis sob certo ângulo da análise, não poderá, porém, ter prevalência sobre aquele interesse que foi juridicamente mais protegido pela lei, por ser ele identificado como um valor prioritário da comunidade. 
Se é verdade que a nossa mais alta Corte de Justiça logrou resolver, com acerto, vários problemas relativos ao aval (como, por exemplo, os do avais em branco e superpostos, resolvido pela Súmula 189 e, de maneira geral, o da própria autonomia do aval, conforme se mostrará a seguir), ainda se nota certa resistência, em alguns julgados, no tocante à autonomia substancial do aval.

Exemplo de tal posiçāo recalcitante nos é dado, presentemente, pela recente decisão da Terceira Câmara do Primeiro Tribunal de Alçada Civil de São Paulo que, por votação unânime, decidiu que "a dívida do avalista não pode ser maior do que a do avalizado".

Indispensável, ao que parece, a transcrição do seguinte trecho do aludido ARESTO:

"Embora a responsabilidade por aval seja autônoma e independente da responsabilidade do avalizado, sua responsabilidade é 'da mesma maneira que a pessoa por ele afiançada' (art. 32 da Lei Uniforme).

Por outro lado, a responsabilidade do avalista é solidária à do aceitante da cambial seu avalizado, em relaçāo ao portador (art. 47 da Lei Uniforme).

Assim, se a responsabilidade é da mesma maneira que a do avalizado, e é solidária, pressupōe que a dívida tenha o mesmo valor tanto para o avalista como para o avalizado.

Ora, a dívida do avalizado, no caso dos autos, por ter sido contraída em moeda estrangeira, deve ser convertida à moeda nacional, à taxa cambial do dia da declaração da falência do avalizado, devedor principal. E a dívida do avalizado deve ser essa mesma dívida contraída em moeda estrangeira convertida à moeda nacional à data da declaração da falência do avalizado.

A dívida do avalista näo pode ser maior do que a do avalizado.

Ademais se o avalista não pode se habilitar na falência do avalizado pela dívida em moeda estrangeira convertida à data do pagamento, porque deve habilitar-se com a dívida em moeda estrangeira convertida à data da declaraçāo da falência do avalizado, haveria a vulneraçāo do art. 49 da Lei Uniforme que declara que a pessoa que pagou uma letra pode reclamar dos seus garantes a soma integral que pagou.

Seria um contrasenso o avalista estar obrigado a pagar dívida em moeda estrangeira convertida à data do vencimento ou do pagamento, e só poder receber do avalizado essa mesma dívida convertida à data da declaração da falência do avalizado". 
Verifica-se, destarte, que a fundamentação do Acórdão está centrada em dois pontos básicos: o primeiro, que procura extrair da expressão "mesma maneira" (art. 32 da Lei Uniforme) e da solidariedade existente entre avalista e avalizado (art. 47 da Lei Uniforme) pressuposição de que a dívida, em conseqüência, deva ter o mesmo valor, e o segundo, embasado no art. 49 da Lei Uniforme, que caracterizaria um "contrasenso", segundo os termos do ARESTO, estar o avalista obrigado a pagar a dívida em moeda estrangeira convertida à data do vencimento ou do pagamento, mas só poder receber do avalizado essa mesma dívida convertida à data da declaração da falência do avalizado.

Vejamos o primeiro ponto.

A argumentação de que a expressāo "da mesma maneira" faz pressupor que a dívida deva ser do mesmo valor é, deveras, claudicante.

Quando a Lei Uniforme usou a expressão "da mesma maneira" quis referir-se, evidentemente, à mesma natureza cambiária da obrigaçăo do avalista e do emitente. Qualquer outra interpretação conduziria à total contradição entre a primeira e a segunda parte do artigo. Se a mesma Lei Uniforme, logo a seguir, diz que a obrigaçāo do aval mantém-se ainda que nula a obrigação do avalizado, nāo poderia ter dito antes que a mesma maneira significaria o mesmo valor, sob pena de, olvidando rudimentos da Lógica, estar contraditória consigo mesma, já que obrigação nula, traduzida em termos quantitativos, equivale a zero e zero é necessariamente diferente, como é óbvio, de qualquer valor, seja este dez, cem ou mil.

A reboque de tão esquálida construção, arrola-se a tênue argumentação de que existe, no caso, a solidariedade. "Se a responsabilidade é da mesma maneira que à do avalizado, e é solidária" - diz o Acórdão - haveria de pressupor-se "que a dívida tenha o mesmo valor tanto para o avalista como para o avalizado".

Ora, a conclusão é inexata. $O$ fato de a obrigação do avalista ser solidária à do devedor principal - ninguém o negará que o seja - não lhe retira a característica de obrigaçāo autonôma, tanto que o avalista poderá ser executado isoladamente pelo credor exeqüente. Se ocorrente tal hipótese, não poderá ele, à evidência, pretender valer-se de eventuais circunstâncias que limitem a dívida do emitente do título.

Ligeiramente melhor - mas igualmente frágil e sem qualquer base científica - é o outro ponto sobre o qual está baseada o ARESTO, ou seja, o "contrasenso", segundo diz o julgado, de estar o avalista obrigado a pagar a dívida em moeda estrangeira convertida à data do vencimento ou do pagamento, mas só 
poder receber do avalizado essa mesma dívida convertida à data da declaração da falência do avalizado.

Tal argumentação não poderá prosperar, segundo entendemos, por duas ordens de razões.

Não poderá prosperar, em primeiro lugar, porquanto a obrigação do avalista não ficará alterada em sua substância ainda que impossibilidade haja de poder ele, nos termos do art. 49, recuperar a soma integral do que pagou. Poder-se-ia lamentar que, no caso, estaria havendo iniqüidade em relação ao avalista que sofre o prejuízo, mas não haveria embasamento jurídico, conforme se verificará a seguir, para sustentar que o avalista não deveria suportar tal prejuízo.

Não poderá prosperar, em segundo lugar, porque se tais argumentos utilizados pelo Acórdão fossem suficientemente fortes para subordinar-se a obrigação do avalista às condições da obrigação do avalizado, estaria esboroada toda a construção da autonomia substancial do aval, sempre acolhida em nosso Direito, quer no regime anterior, do Decreto no 2.044, quer na disciplina da Lei Uniforme.

Analisemos, então, esse segundo ponto sobre o qual se terá baseado o Acórdão à luz das duas consideraçōes retro-aludidas.

A primeira ponderação que apresentamos diz respeito ao direito do analista de voltar-se contra o seu avalizado.

O direito de regresso do dador do aval contra o seu avalizado é, em princípio, sempre possível, tanto na hipótese de falência quanto na hipótese de concordata do eminente do título. E isso ocorre, evidentemente, seja por força do art. 49 da Lei Uniforme, seja pelo fato de que o avalista não se beneficia pelo advento da concordata do eminente.

Lembre-se, a propósito, que o art. 148 da Lei de Falências estabeleceu que:

“A concordata não produz novaçāo, nāo desonera os coobrigados com o devedor, nem os fiadores deste e os responsáveis por via de regresso".

O Supremo Tribunal Federal, absolutamente consciente da autonomia substancial do aval, decidiu, com inteiro acerto, que o credor exeqüente, que havia recebido parte de seu crédito na concordata do emitente, tinha o direito de cobrar do avalista o restante de seu crédito cambiário. 
"Admitir-se o contrário" - diz o ARESTO - "isto é, que satisfeito o pagamento do título, em 75\% pelo concordatário, estaria liberado o avalista da obrigação de pagar os $25 \%$ restantes do débito, seria nulificar o aval, que exatamente existe, para cobrir o risco da insolvência do devedor".

Vale isto dizer que o "contrasenso" a que se refere o R. Acórdão, na verdade, é relativo. Esse direito que tem o avalista de voltar-se contra o avalizado pela totalidade do que pagou, permanece, na essência, inalterado, seja porque ele poderá, na hipótese de concordata, sub-rogado que está nos direitos do credor satisfeito, habilitar-se pelo valor do que pagou, seja porque, na hipótese de falência, habilitar-se-á, igualmente, pela totalidade do que pagou, ainda que não venha a receber a soma integral do que terá desembolsado.

$\mathrm{O}$ argumento de que, na concordata, o avalista sub-rogado nos direitos do credor, irá receber apenas a percentagem fixada, ou que, na falência, terá o seu crédito estancado pela inexistência da correção monetária (a prevalecer essa tese nos tribunais, atualmente bastante divididos), não poderá alterar o conteúdo de sua própria obrigação, ainda que ele venha a arcar, efetivamente, com tal prejuízo.

Nesse sentido, inteira procedência tem a liçāo de MIRANDA VALVERDE (Comentários à Lei de Falências, vol. II, pág. 247), oportunamente invocada pelo julgado do S. T. F.. Comentando o retromencionado art. 148 da Lei Falimentar, asseverava VALVERDE que

"Se o credor recebe a percentagem da concordata, volta-se contra o coobrigado para obter o restante do crédito, que completará o seu pagamento integral. Se resolve agir imediatamente contra o coobrigado e dele consegue o pagamento integral, ficará o coobrigado sub-rogado nos direitos do credor satisfeito e receberá do concordatário, exclusivamente, a percentagem, sofrendo o prejuízo do restante".

CARVALHO DE MENDONÇA ("Tratado de Direito Comercial Brasileiro", vol. $8,1971, \S 1161$, págs. 398 e 399), "comentando o art. 114 da anterior Lei n-2.024, praticamente do mesmo teor do atual art. 148, da Lei Falimentar, pouco atrás transcrito, prelecionava:

"Foi justamente temendo não ser pago integralmente que o credor exigiu coobrigados ou fiadores; o credor forçado pelas circunstâncias a aceitar a concordata, presume-se ter feito o que a prudência lhe recomendava e ter obrado em boa fé. Perdessem os credores os direitos que tinham contra os coobrigados, condenado estaria $o$ instituto da concordata, pois tanto importaria excluir tais 
credores das deliberaçōes concordatárias, e esta exclusāo tornaria na maioria dos casos irrealizável a concordata.

O fiador on o coobrigado, que paga ao credor o restante da dívida, nāo pode exigir do concordatário a quantia que pagou, nem mesmo a porcentagem da concordata sobre a mesma quantia, pois, se assim fosse, a remissāo obtida pelo devedor ficaria completamente ilusória; dava-se uma troca de pessoas, mas a situação continuaria a mesma. Em vez de pagar ao credor direto, teria de pagar ao coobrigado ou ao fiador.

O concordatário tem apenas obrigaçāo natural de satisfazer ao coobrigado ou ao fiador quanto estes por ele pagaram".

O pensamento dos dois grandes juristas mencionados convergem no mesmo sentido: ambos entendem que o coobrigado responde pelo restante da dívida, mas que não terá direito de cobrar do concordatário mais do que este devia na concordata sob pena de deixar de ter sentido a remissão por ele obtida.

É exatamente nesse ponto que reside o equívoco em que incorreu o Acórdão: não é o fato de não ser possível ao avalista recuperar a soma integral do que pagou, pela circunstância mesma da concordata, que ele terá, por isso, a cessação de sua responsabilidade perante o $3^{\circ}$ credor.

Não se pode inverter a verdadeira ordem das coisas. A irrecuperabilidade da quantia total desembolsada pelo avalista não poderá ter o condão, como quer a tese do Acórdão, de desmanchar a sua responsabilidade perante o $3^{\circ}$ credor, definida como obrigação autônoma, que subsiste mesmo no caso de ser nula a obrigação por ele avalizada.

No direito francês, por exemplo, vamos encontrar igualmente norma expressa no mesmo sentido, já que o art. 545 do Código de Comércio atual estabeleceu que:

"Nonobstant le concordat, les créanciers conservent leur action pour la totalité de leurs créances contre les coobligés du failli".

Antes da lei de 1838 , vigoravam naquele país as disposiçōes do famoso Code de Commerce de 1807, cuja solução, para o presente caso, era menos favorável à manutenção da garantia. Anteriormente, como nos esclarece PERCEROU ("Faillites, Banqueroutes et Liquidations Judiciaires", in "Traité Général de Droit Commercial”, vol. II, Paris, Rousseau Editeur, 1913, pág. 469)

"les remises profitaient au codébiteur, et elles le libéraient dans la même proportion que le failli concordataire, mais seulement lorsque le créancier avait pris part au concordat et en avait voté les clauses; dans le cas contraire, le créancier conservait son action intégrale contre le coobligé". 
Veja-se, pois, que a norma do Código de 1807 (que só reservava ao credor o direito de voltar-se integralmente contra o coobrigado quando ele não tivesse tomado parte na concordata, nem votado as cláusulas desta) foi substituída, desde 1838, por outra que deu ao credor proteção muito maior.

Segundo a redação retrotranscrita do art. 545 do Código Comercial, dúvida não parece existir, nem na doutrina, nem na jurisprudência, quanto ao direito que tem o credor de voltar-se integralmente contra aquele que prestou a garantia.

Diz-nos PERCEROU a esse respeito:

“Que l'on suppose par exemple une créance de 100, garantie par une caution qui reste solvable, le débiteur principal tombant en faillite.

Le créancier produt à cette faillite pour le montant nominal de son droit, soit 100, écartant ainsi la production parallèle de la cantion (art. 543 C. Com.) Puis un concordat judiciare (auquel le créancier participe ou non, peu importe) intervient et fait an failli une remise de 75\%. Le droit du créancier visà-vis du débiteur principal tombe ainsi à 25. Mais cette remise ne profite pas à la caution, qui reste tenue four le tout, c'est-à-dire pour 100".

As explicações do grande jurista francês servem para mostrar, de maneira incontroversa, que a solução preconizada pelo julgado de nosso Tribunal a respeito de tal matéria, já nāo teria condiçōes de prevalecer, nos tribunais franceses, desde 1838, sendo a mesma situação para os codevedores solidários do falido, igualmente não liberados pela concordata, conforme esclarece o autor em nota de rodapé com jurisprudência tranqüila a respeito do assunto.

$\mathrm{Na}$ Itália, para ficar apenas em mais um exemplo em termos de direito compardo, esclareceu BONELLI que ("Del fallimento", vol. II, 1938, págs. 495 e 496):

É naturale che non resti impedita dal concordato l'azione verso i coobbligati. Se anche il concordatario à debitore principale, resta integra l'azione contro il fidejussore; integra per l'intiero importo del debito, finchè nulla siasi riscosso dal concordatario; integra per la parte residuale, quando siasi incominciato ad incassare e dopo incassato il dividendo. E così resta integra l'azione ipotecaria contro il fidejussore reale, sebbene non personalmente coobbligato, ed anche contro il terzo possessore".

Após esclarecer a subsistência integral da responsabilidade do coobrigado do concordatário, mostra o grande autor peninsular que ele se sub-roga nos 
direitos do credor satisfeito pela quantia paga, mas apenas até o limite do que for pago na concordata, não tendo ação alguma para cobrar o que terá pago a mais.

\begin{abstract}
"Il coobligato o fidejussore che paga subentra" - Diz-nos BONEiLLI - "per la somma pagata, nel diritto del creditore sul dividendo; ma esaurito questo, nemmeno il fidejussore ha più diritto di far valere verso il concordatario alcuna azione per ciò che ha pagato in più dell'importo del dividendo. Non già che non s'operi anche in questo caso il subingresso legale, la surrogazione del fidejussore nei diritti e nella posizione del creditore; magli è che manca appunto anche al creditore, per effetto del concordato, l'azione per la parte rimessa, e nemo plus juris in alium transferre potest quan ipse habet. Nè il fidejussore può imputargli a colpa questa menomazione di diritti, che non procede dal fatto di lui, ma bensi della massa, cioè di un ente collettivo, di cui egli stesso, fidejussore, fa parte.
\end{abstract}

Claro está, portanto, que a circunstância de vir o avalista sofrer um prejuízo, decorrente da irrecuperabilidade da quantia total que desembolsou, não poderá, como parece ser de comezinho senso jurídico, fazer esboroar todo o princípio da autonomia substancial do aval.

Passemos, agora, ao exame da segunda razão pela qual julgamos nāo ser possível a prevalência da tese do Acórdão de que se cuida. Referimo-nos, especificamente, à questão relativa às funçōes do instituto do aval.

As expressōes do julgado do S. T. F., invocado por nós linhas atrás, ("que exatamente existe para cobrir o risco da insolvência do devedor") revelam a preocupação dos julgadores com a funçāo do instituto, sobre a qual tivemos a ocasiāo de discorrer anteriormente (Parte II). Se o aval representa um reforço de garantia, se se destina a conferir ao credor cambiário a maior segurança possível quanto ao recebimento do valor da soma cambiária, como entender-se que a obrigação do avalista não possa ser maior do que a do avalizado, se, na verdade, não foi a do avalista quem cresceu, mas sim a do avalizado que diminiui?

Caberia lembrar, de passagem, que o próprio Primeiro Tribunal de Alçada Civil, por votação unânime, em Acórdão de sua 6ª Câmara, num caso que envolvia a subsistência da responsabilidade do avalista perante o banco credor, não obstante a concordata da empresa emitente do título, decidiu que o recurso interposto pelo avalista "careceria do menor fundamento jurídico".

Transcreva-se o teor do ARESTO pela sua extrema pertinência com o problema da autonomia substancial do aval: 
"Cumpre sublinhar, de início, que o apelante é avalista, estando a sua responsabilidade definida no título e no contrato de fls. 6-7. Assim, lhe nāo é lícito arguir as exceçōes próprias envolvendo matéria extracartular como pretende. Sua responsabilidade, decorrente do aval, é solidária ao da devedora principal, sendo, outrossim, autônoma em relaçāo ao credor que podera executá-lo isoladamente. É o que vem sendo proclamado em inúmeros precedentes (cf. "Revista dos Tribunais", vol. 498/219; idem, vol. 509/269, entre outros).

De outra parte, a questāo agitada referente à concordata, em nada prejudica a execução ajuizada pelo Banco credor, uma vez que o apelante é avalista da firma concordatária.

O privilégio outorgado aos concordatários nāo atinge os avalistas subsistindo as cláusulas do contrato assinado. É também o que tem sido proclamado (cf. "Revista do Tribunais", vol. 506/90; Revista dos "Julgados", ed. LEX, vol. 59/165)".

Verificamos que, pelos julgados retromencionados, embora estejamos diante do instituto da concordata e não no da falência, a responsabilidade do avalista não sofre alterações em virtude de ter-se alterado a responsabilidade o avalizado concordatário. Não se trata, como já se disse, de ser a obrigação dele maior do que a do avalizado. Ela simplesmente permanece íntegra, não se modificando em virtude de circunstâncias que favoreçam o avalizado, vez que se trata de obrigação autônoma.

Compreende-se, por certo, o espírito que terá orientado a posição dos Eméritos Julgadores no caso de que se cuida. Parece ferir o nosso senso de eqüidade lidar com a idéia de que o avalista, provavelmente alheio ao próprio destino do mútuo efetuado em favor do emitente, ainda tenha que ficar em posição desvantajosa, em relação a este, por nao ser destinatário das disposições legais protetoras da atividade deste último.

É perfeitamente compreensível que, nessa ordem de considerações, procure-se justificar, no plano dogmático, a identidade da dívida, alegando-se que a autonomia não poderá ir ao ponto de tirar do avalista o direito de opor as defesas pessoais que são próprias do avalizado, como o quer PONTES DE MIRANDA (Tratado de Direito Privado, tomo XXXIV, pág. 385), invocado pelo Acórdão.

Essa posição do grande jurista, entretanto, além de inaceitável, é praticamente isolada no contexto da doutrina do aval, tanto aqui como alhures.

SILVA PINTO (Ob. cit., pág. 227) chega mesmo a afirmar que a liçāo de PONTES sobre a natureza jurídica do aval é "extremamente original e peculiar, porque nāo obstante admitir ele a possibilidade de oposição, pelo avalista, das 
exceções pessoais do avalizado, afirma que aval não é garantia, mas mera obrigação equiparada, contrariando a natureza das coisas e opondo-se ao texto expresso do art. 14 da lei cambiária brasileira".

Retornando-se à questão relativa ao resultado iníquo a que se pode chegar em decorrência da autonomia substancial do aval, cumpre sejam acrescentadas algumas considerações.

Em primeiro lugar, não deve ser considerado relevante o caráter gratuito ou oneroso do aval, pois embora ele seja normalmente gratuito, não teria a eventual onerosidade o condão de alterar-lhe a natureza. Como salienta SILVA PINTO (ob. cit., pág. 237) e como, de resto, a doutrina e a jurisprudência italianas já haviam precisado, estamos diante de um ato neutro, "que pode adquirir a coloração de gratuidade ou de onerosidade de acordo com as circunstâncias em que é prestado ${ }^{(1)}$.

Não se poderá, assim, por mais que as circunstâncias do caso concreto possam carregar nas cores da desventura sofrida por aquele avalista que, sem nada ter recebido para praticar o ato e sem nada ter a ver com a transaçāo, se vê compelido a pagar mais do que o próprio avalizado, deixar de reconhecer que a sua obrigação, espontaneamente assumida no título de crétido, engaja-se na própria função econômica da circulação da riqueza de tal espécie de título.

Se se devesse levar em consideração, em matéria de títulos de crédito, a eqüidade ou inequidade das obrigações assumidas em cada caso concreto, provavelmente teríamos de renunciar ao resultado tāo incansavelmente perseguido pela doutrina na sistematização de certos princípios jurídicos que, independentemente de eventuais vícios da relaçāo de emissão, puderam garantir, para o $3^{\circ}$ portador de boa-fé, a plena aquisição do direito mencionado no título de crédito.

Embora tal assertiva já terá sido feita ao longo do presente trabalho, caberia insistir, ainda uma vez, na caracterização do aval como garantia cambiária típica, de conformidade com a doyutrina mais recente a respeito da matéria.

Não iremos reproduzir, evidentemente, tudo aquilo que já se disse nos capítulos precedentes respeito da evolução histórica do instituto do aval e de todo o debate que em torno dele se travou.

Relembre-se, apenas, que, em matéria de aval, não é possível tirar-se esta ou aquela conclusão com base exclusiva no pensamento de um punhado de autores, por mais brilhantes que sejam.

(1) Apud SILVA PINTO, ob. cit., pág. 237. 
É preciso captar o atual estágio da doutrina dentro de um contínuo histórico. Não haveria mais sentido, hoje, em falar-se, por exemplo, na doutrina do aval-fiança. Assim como também não teria mais sentido, desde a Lei Uniforme, insistir-se na tese diametralmente oposta, sustentada por parte da doutrina alemã e na Itália por BONELLI, no sentido de que a autonomia do aval dar-se-ia, também, no plano formal, embora, na nossa lei de duplicatas, o aval esteja disciplinado de maneira mais próxima desta doutrina do que em relação à Lei Uniforme.

Pouco adianta hoje, igualmente, insistir-se na "objetivação" do aval, se não se esclarece o sentido preciso dessa expressão, que é o de desvincular o ato do aval da firma garantida, mas não a ponto de prescindir da existência dela, vale dizer, objetiva-se o aval como garantia substancialmente autônoma, mas, apesar dessa objetivação, continuaria ela formalmente acessória.

Foi na tentativa de superar essas dificuldades todas, a nosso ver, que a doutrina mais recente propendeu para caracterizar o aval como garantia cambiária típica, podendo ser considerados como partidários de tal corrente autores como: ROSSI, ALEGRIA, MOSSA, além de outros que, com maiores ou menores matizes, a adotam. Poder-se-ia acrescentar, também, que os autores que simultaneamente defendem a acessoriedade formal e a noção de garantia "objetiva", enquadram-se, de maneira mais ou menos adequada, nessa mesma corrente.

Em síntese - que a esta altura não poderia deixar de ser grosseira diríamos que a caracterização do aval como garantia cambiária típica significa considerar, sobretudo, que se trata de obrigação distinta da obrigação do avalizado, revestida de literalidade e autonomia, sendo certo que essa última característica se dá de maneira absoluta no plano substancial, e de maneira apenas relativa no plano formal.

Assim, não se pode deixar de reconhecer, quer em face do texto da Lei Uniforme, quer no regime do nosso anterior 2.044 (que era, a nosso ver, melhor do que a Lei Uniforme), quer em relação à doutrina mais recente sobre a matéria, que a tese esposada pelo R. ARESTO, infelizmente, não poderá deixar de ser recebida com grande perplexidade - e mesmo estarrecimento - por todos aqueles que tem por missáo pensar o Direito e, se vier a prevalecer na nossa mais alta Corte de Justiça, o que não acreditamos, representará doloroso retrocesso do direito cambiário em nosso país.

\section{BIBLIOGRAFIA}

MESSINEO, Francesco, "Manuale di Diritto Civile e Commerciale”, Giuffrè, , Milano, 1972, págs. 367 e seguintes. 
ASQUINI, Alberto, “Titoli di Credito". Cedam, Padova, 1966, págs. 256 e seguintes.

VIVANTE, Cesare, "Trattato di Diritto Commerciale", Francesco Vallardi, Milano, 1935, Vol. III § 94, nos 1221 e 1240, págs. 317 e seguintes.

ALEGRIA, Héctor, "El aval - Tratamiento completo de su problemática jurídica", Astrea, Buenos Aires, 1975.

DE SEMO, Giorgio, "Trattato di Diritto Cambiario", Cedam, Padova, 1963, nos 479 a 498 , págs. 450 e seguintes.

BANFANTI, Mario Alberto \& GARRONE, José Alberto, "De los Títulos de Crédito", Abeledo-Perrot, Buenos Aires, 1976, nºs 208 a 235, págs. 401 e seguintes.

REQUIĀO, Rubens, “Curso de Direito Comercial”, Saraiva, 1980, 2 volume, págs. 345 e seguintes.

ROBLOT, René “Les Effets de Commerce”, Sirey, Paris, 1975, págs. 204 e seguintes.

RODIÈRE, René, “Droit Commercial”, Dalloz, 1975, págs. 69 e seguintes.

MUÑOZ, Luiz, "Titulos-Valores", Editora Argentina, Buenos Aires, 1973, págs. 451 e seguintes.

EUNÁPIO BORGES, Joāo, "Do Aval", Forense, 4⿳亠丷 edição, 1975.

MAGARINOS TORRES, "Nota Promissória”, Saraiva, 1943, 5" Edição, págs. 211 e seguintes.

LACERDA, Paulo Maria de, "A Cambial no Direito Brasileiro", Ed. Leite Ribeiro \& Maurillo, Rio de Janeiro, 1921, págs. 149 e seguintes.

CARVALHO DE MENDONÇA, J. X., "Tratado de Direito Comercial Brasileiro", Livr. Freitas Bastos, 1922, Rio de Janeiro, vl. V, $2^{\mathrm{a}}$ parte, $\$ \$ 747$ e seguintes, 346 e seguintes.

PONTES DE MIRANDA, "Tratado de Direito Cambiário" - Letra de Câmbio - Max Limonad, 1954, 2ª ediçāo, vol. 1, págs. 245 e scguintes.

ROSSI, Guido, “L'A vallo come Garanzia Cambiaria Tipica”, Giulfrè, Milano, 1962.

GUALTIERI, Giuseppe, "I Titoli di Credito", Ed. Torinese, Torino. 1953, págs. 214 e seguintes.

SALANDRA, Vittorio. "Curso de Derecho Mercantil”, Ed. Jus, México, 1949. Trad. Jorge Barrera Graf. págs. 277 e seguintes.

SOLMI, Arrigo. "Sulla origine della voce 'avallo" ", in Rivista Di Diritto Commerciale. vol. 8, I, págs. 720 a 724 .

BONELLI, Gustavo. "Sulla natura giuridica dell'avallo", Rivista Di Diritto Commerciale, vol.9, Il parte, págs. $116 \mathrm{c}$ seguintes. 
MATTEUCCI, Mario, “La forma dell'avallo e il regolamento cambiario uniforme”, in Rivista "Banca, Borsa e Titoli di Credito", 1르 parte, fasc. 3, 1934, págs. 142 a 154.

ASCARELLI, Tullio. "Teoria Geral dos Títulos de Crédito”, Saraiva, 1943.

JOĀO ARRUDA. "Decreto n².044”, I Volume, Escolas Profissionais Salesianas, 1914, São Paulo, págs. 65 e seguintes.

SÄRAIVA, José. “A Cambial”, $§ 90$ a 97, págs. 265 a 287.

MARTORANO, Federico. "I Titoli di Credito", Ed. Morano, 1970, Nápoles, págs. 492 e seguintes.

RUBIO, Jesus. “Derecho Cambiario”, Gráficas Hergon, Madrid, 1973, págs. 313 e seguintes.

GA VALDA Christian \& STOUFFLET Jean. "Droit Commercial”, Presses Universitaires de France, Paris, 1978, págs. 194 e seguintes.

DE LUCCA Newton. “Aspectos da Teoria Geral dos Títulos de Crédito”, Pioneira, 1979.

SILVA PINTO, Paulo J. "Direito Cambiário", Capítulos V e VI, págs. 149 a 187 e 188 a 257. 